\title{
Gambaran Kesadaran Masyarakat terhadap Kawasan Tanpa Rokok di Indonesia
}

\section{Public Awareness on Smoke Free Area in Indonesia}

\author{
Ingan U. Tarigan ${ }^{1}$, Anni Yulianti ${ }^{1}$ \\ 1) Pusat Penelitian dan Pengembangan Sumber Daya dan Pelayanan Kesehatan, Jalan Percetakan Negara No. 29 Jakarta \\ 10560, Indonesia \\ Korespondensi: ingantr@yahoo.com
}

Submitted: 18 Juli 2019, Revised: 27 Agustus 2019, Accepted: 29 Agustus 2019

https://doi.org/10.22435/jpppk.v3i2.2655

\begin{abstract}
Abstrak
Merokok merupakan salah satu faktor risiko terhadap penyakit yang membahayakan, seperti jantung, stroke, kanker, dan lain sebagainya. Perilaku masyarakat khususnya perokok aktif yang merokok di sembarangan tempat masih cukup memprihatinkan. Perokok membebankan risiko merokok bukan hanya pada diri sendiri tetapi juga kepada orang lain yang ada di sekitarnya. Analisis dilakukan dengan menggunakan data GATS (Global Adult Tobacco Survey) 2011, dimana desain penelitian adalah cross sectional. Pemilihan sampel menggunakan teknik sampling proportional probabilitas to size (PPS). Hasil dari analisis antara lain: masyarakat yang terpapar rokok di dalam rumah lebih banyak pada kelompok laki-laki dibandingkan perempuan, yang terbanyak pada kelompok umur 45-64 tahun dengan pendidikan tidak tamat SD, tempat tinggal di pedesaan, dan pekerjaan wiraswasta. Kebijakan keluarga yang mengizinkan merokok dalam rumah sebesar $46,9 \%$, dan seseorang yang merokok dalam rumah setiap hari mencapai $62,5 \%$. Masyarakat yang terpapar rokok di ruang kerja sebesar $51,4 \%$, dan kantor yang mengizinkan merokok dalam ruang kerja sebesar $38,4 \%$ dan yang tidak ada kebijakan sebesar $19,8 \%$. Terpapar rokok di kantor pemerintahan $66,4 \%$, di universitas $55,3 \%$, di sekolah atau fasilitas pendidikan lainnya $40,3 \%$, di fasilitas keagamaan $17,9 \%$, di fasilitas kesehatan $18,4 \%$, di bar atau klub $91,8 \%$, dan transportasi umum $70,8 \%$. Hasil ini dapat menjadi data dasar untuk mengembangkan intervensi program pengendalian tembakau yang efektif, termasuk menyediakan layanan berhenti merokok, terutama di fasilitas kesehatan. Pemerintah pusat dan daerah perlu meningkatkan sosialisasi tentang bahaya merokok di tempat-tempat umum dan dampaknya terhadap masyarakat khususnya yang bukan perokok; yaitu dengan membuat peraturan yang jelas dan tegas tentang pelarangan merokok di tempat-tempat umum dan memberikan sangsi yang tegas terhadap yang melanggar peraturan tersebut. Upaya layanan berhenti merokok dapat dilaksanakan dengan meningkatkan kegiatan promosi oleh tenaga kesehatan, sosialisasi 'Quitline' Kementerian Kesehatan, skrining CO2, bantuan konseling dan mengembangkan metode terapi berhenti merokok bagi para perokok aktif di berbagai fasilitas kesehatan yang tersedia.
\end{abstract}

Kata kunci: rokok, perokok pasif, pengendalian tembakau

\section{Abstract}

Smoking is one of the risk factors for severe diseases, such as heart disease, stroke, cancer, and so on. The behavior of active smokers who smoke arbitrarily at many public places is still quite alarming. Smokers impose the risk of smoking not only on themselves but also to others around them. The analysis was performed using GATS (Global Adult Tobacco Survey) 2011 data, where the research design was cross-sectional. The sample selection uses a proportional probability to size (PPS) sampling technique. The results of the analysis show people who are exposed to cigarettes in the house are mostly males than females with the characteristics were at age groups 45-64 years old, educational level was not completed elementary school, living in rural areas, and self-employee. Family policies that allow smoking in the home were $46.9 \%$, and someone who 
smokes in the house every day reaches $62.5 \%$. People who are exposed to cigarettes in the workspace were $51.4 \%$ and offices that allow smoking in the workspace were $38.4 \%$ and those without any 'free smoking area' policy were $19.8 \%$. Exposure to cigarettes was $66.4 \%$ in government offices, $55.3 \%$ in universities, $40.3 \%$ in schools or other educational facilities, $17.9 \%$ in religious facilities, $18.4 \%$ in health facilities, $91.8 \%$ in bars or clubs, and $70.8 \%$ in public transportation. These results could be a reference or base evidence in developing an effective tobacco control program, including providing smoking cessation services. Central and local governments need to increase awareness about the risk of smoking in public places and their impact on public health, especially for non-smokers, by issuing a strict regulation on free smoking areas in public places and enforce punishment to people who violate these regulations. The efforts to stop smoking services can be implemented by increasing promotion activities by health workers, socialization of the Ministry of Health 'Quitline', CO2 screening, counseling assistance and developing methods of smoking cessation therapy for active smokers in existing health facilities.

Keywords: cigarette exposure, passive smokers, tobacco control

\section{Pendahuluan}

Merokok memberikan dampak buruk bagi kesehatan, rokok dapat berisiko terhadap berbagai macam penyakit yang berbahaya dan mematikan. Merokok tidak hanya merugikan perokok, namun juga membahayakan orang di sekitarnya. Ironisnya perokok pasif lebih banyak menghirup kandungan bahan kimia rokok dibandingkan dengan yang dihirup oleh perokoknya. Perokok pasif adalah orang yang bukan perokok tetapi menghisap asap rokok orang lain yang ada di sekitarnya.

Menurut PP Nomor 109 tahun 2012 tentang Pengamanan Bahan yang Mengandung Zat Adiktif Berupa Produk Tembakau Bagi Kesehatan, disebutkan tentang Kawasan Tanpa Rokok (KTR). KTR adalah area yang dinyatakan dilarang untuk kegiatan merokok atau kegiatan memproduksi, menjual, mengiklankan, dan/atau mempromosikan produk tembakau. Penetapan Kawasan Tanpa Rokok (KTR) merupakan upaya perlindungan terhadap masyarakat dari risiko ancaman gangguan kesehatan karena lingkungan tercemar asap rokok. ${ }^{1}$ Namun sampai saat ini, belum semua masyarakat mengetahui dan memahami dimana saja kawasan tanpa rokok yang harus diterapkan di masyarakat.

Dalam PP Nomor 109 tahun 2012 disebutkan Kawasan Tanpa Rokok (KTR) terdiri dari 1) Fasilitas kesehatan; 2) Tempat proses belajar mengajar; 3) Tempat anak bermain; 4) Tempat ibadah; 5) Angkutan umum; 6) Tempat kerja; dan 7) Tempat umum dan tempat lain yang ditetapkan. ${ }^{1}$ Terkait kebijakan, sampai akhir Desember 2014 terdapat 49 Peraturan daerah tingkat kabupaten/kota, 102 peraturan bupati/walikota dan 13 provinsi di
Indonesia yang memiliki kebijakan Kawasan Tanpa Rokok. ${ }^{2}$ Implementasi kebijakan KTR tidak saja dimaksudkan untuk memenuhi hak perokok pasif untuk menghirup udara bersih dan sehat, namun juga diharapkan membantu perokok aktif untuk dapat menahan atau menunda kebiasaan merokoknya dan dapat menjadi langkah awal perokok aktif untuk berhenti merokok.

Perokok membebankan risiko merokok bukan hanya untuk diri sendiri tetapi juga kepada orang lain di sekitarnya. Menghisap asap rokok orang lain tiga kali lipat lebih berbahaya dibandingkan perokok aktif.

Sumber asap rokok seringkali berasal dari orang-orang terdekat yang rutin merokok di sekitarnya. Banyak anggota keluarga yang merokok di dalam rumah, tanpa memikirkan anggota keluarga lain yang tidak merokok. Prevalensi perokok aktif laki-laki dewasa lebih banyak dibandingkan perempuan, karenanya perempuan anak-anak dan balita adalah kelompok yang paling banyak terpapar asap rokok, termasuk di dalam rumah dibandingkan laki-laki dewasa.

Prevalensi perokok pasif di Indonesia menurut data Riset Kesehatan Dasar (Riskesdas) Kementerian Kesehatan, pada tahun 2007 sebesar $40,5 \%$ penduduk semua umur (91 juta) terpapar asap rokok di dalam rumah, dan meningkat pada tahun 2010 menjadi 92 juta penduduk. ${ }^{3,4}$ Riskesdas juga menyebutkan prevalensi perokok aktif usia $\geq 15$ tahun di Indonesia pada tahun 2007 sebesar 34,2\% dan $34,3 \%$ di tahun 2010. ${ }^{3,4}$ Hasil Global Adults Tobacco Survey di Indonesia menjelaskan bahwa $51,3 \%$ orang dewasa bekerja di dalam ruangan 
dan terpapar rokok, 85,4\% terpapar di restoran dan $70 \%$ di transportasi umum. ${ }^{5}$ Hasil penelitian di tiga kota di Indonesia menunjukkan bahwa kadar nikotin ditemukan pada area bebas rokok di restoran dan tempat hiburan. Hal ini mengindikasikan bahwa tidak ada area khusus yang aman untuk perokok pasif, sehingga perlu didukung peraturan terkait bebas asap rokok di tempat-tempat umum. ${ }^{6}$ Tingginya jumlah perokok aktif akan semakin meningkatkan risiko keterpaparan perokok pasif terhadap dampak lanjutan bagi kesehatan akibat menghirup asap rokok orang lain. Hal ini dapat diperburuk jika penegakan aturan KTR lemah dan atau kurangnya pemahaman masyarakat akan penerapan KTR. Analisis terkait hal ini dibutuhkan sebagai data dasar program pengendalian tembakau, khususnya dalam merumuskan penegakan aturan KTR. Tujuan analisis untuk mengetahui gambaran kesadaran masyarakat terhadap Kawasan Tanpa Rokok (KTR).

\section{Metode}

Analisis dilakukan secara deskriptif dengan menggunakan data Global Adult Tobacco Survey (GATS) 2011.5 Desain penelitian dalam penelitian GATS adalah cross sectional.

Rancangan sampel bertingkat ganda dengan kluster blok sensus. Kerangka sampling yang digunakan untuk desain sampel GATS Indonesia adalah blok sensus, yang diperoleh dari data Sensus Penduduk tahun 2010. Pada tahap pertama, 100 primary sampling unit (PSU) (50 di perkotaan dan 50 di pedesaan) yang dipilih dengan menggunakan teknik sampling proportional probabilitas to size (PPS). Total sampel sebesar 8,994 rumah tangga, dimana setiap rumah tangga terpilih, salah satu responden dipilih secara acak untuk di wawancarai dengan usia 15 tahun atau lebih. Informasi direkam pengumpul data dengan perangkat eletronik iPAQ. Responden yang berhasil diwawancara lengkap sebesar 8,305 individu, dengan tingkat respon sebesar $94.3 \%$. Responden yang terpilih dalam wawancara bervariasi, ada perokok aktif, mantan perokok, dan yang tidak pernah merokok. Pada saat wawancara akan ditanyakan kepada responden mengenai kebijakan merokok dalam rumah, apakah diizinkan atau tidak merokok dalam rumah; kemudian jika responden bekerja, ditanyakan terkait kebijakan kantor merokok dalam ruangan tertutup. Selain itu, responden juga ditanyakan, apakah satu bulan terakhir berkunjung ke tempat-tempat umum (kantor pemerintahan, universitas, sekolah, fasilitas keagamaan, fasilitas layanan kesehatan, rumah makan, bar/klub malam, dan transportasi umum). Jika pernah berkunjung satu bulan terakhir, ditanyakan apakah ada melihat orang merokok di fasilitas umum tersebut.

GATS dilakukan atas kerjasama yang dilakukan oleh Badan Pusat Statistik dan Badan Penelitian dan Pengembangan Kesehatan (Balitbangkes) Kementerian Kesehatan RI dan didukung oleh WHO dan CDC Atlanta. ${ }^{5}$

\section{Hasil \\ Keterpaparan Perokok di dalam Rumah}

Tabel 1 secara umum status perokok aktif tertinggi adalah laki-laki, sementara berdasarkan kelompok umur, pendidikan dan pekerjaan, perokok aktif tertinggi adalah kelompok umur 15-44 tahun. Kemudian jika dilihat berdasarkan tempat tinggal, perokok aktif tertinggi ada di daerah pedesaan.

Tabel 2 menunjukkan bahwa kebijakan merokok di dalam rumah bervariasi. Kebijakan keluarga yang mengizinkan merokok di dalam rumah, tertinggi adalah pada kelompok merokok aktif (53.4\%), tidak pernah merokok (43.6\%), dan mantan perokok $(41.3 \%)$. Hal ini menunjukkan bahwa keluarga yang salah satu anggota keluarganya perokok aktif cenderung mengizinkan seseorang merokok di dalam rumah. Hal ini berbeda jika dilihat pada kelompok mantan perokok, dimana keluarga dengan mantan perokok yang tidak mengizinkan merokok dalam rumah cenderung lebih tinggi. Perbedaan ini terjadi karena kemungkinan keluarga dengan mantan perokok lebih memahami dampak merokok terhadap kesehatan.

Jika keluarga yang mengizinkan merokok dalam rumah, ditanyakan seberapa sering "seseorang" merokok dalam rumah, ternyata pada kelompok perokok aktif, yang setiap hari merokok dalam rumah mencapai $78.8 \%$, kelompok tidak pernah merokok 55\%, dan kelompok mantan perokok sebesar 36.1\%. Secara keseluruhan, keluarga yang mengizinkan merokok di dalam rumah, dan merokok setiap hari mencapai $62.5 \%$.

Tabel 3 menggambarkan penjelasan 
Tabel 1. Karakteristik Responden Berdasarkan Status Perokok

\begin{tabular}{lccc}
\hline \multicolumn{1}{c}{ Karakteristik } & \multicolumn{3}{c}{ Status Perokok } \\
\cline { 2 - 4 } & $\begin{array}{c}\text { Perokok Aktif } \\
(\mathbf{n = 2 . 8 5 5 )}\end{array}$ & $\begin{array}{c}\text { Mantan Perokok } \\
(\mathbf{n}=\mathbf{5 5 5})\end{array}$ & $\begin{array}{c}\text { Tidak Pernah Merokok } \\
(\mathbf{n}=\mathbf{4 . 8 9 5})\end{array}$ \\
\hline Jenis Kelamin & & & \\
Laki-laki & 67,1 & 11,0 & 21,9 \\
Perempuan & 2,8 & 2,1 & 95,1 \\
Kelompok Umur (tahun) & & & \\
15-24 & 39,0 & 1,2 & 59,8 \\
25-44 & 39,3 & 3,2 & 57,5 \\
45-64 & 36,4 & 6,9 & 56,6 \\
65+ & 29,1 & 13,8 & 57,1 \\
Pendidikan & & & \\
Tidak Tamat SD & 38,0 & 6,8 & 55,2 \\
Tamat SD & 37,2 & 5,9 & 57,0 \\
Tamat SLTP & 31,9 & 3,9 & 64,2 \\
Tamat SLTA & 33,7 & 8,0 & 58,3 \\
Perguruan Tinggi & 27,6 & 10,9 & \\
Tempat Tinggal & & & 60,7 \\
Perkotaan & 31,9 & 7,3 & 56,7 \\
Pedesaan & 37,7 & 5,6 & \\
Pekerjaan & & & 45,6 \\
Pegawai/karyawan & 46,8 & 7,6 & 41,8 \\
Wiraswasta & 50,3 & 7,8 & 84,3 \\
Pelajar/Ibu RT/Pengangguran & 11,3 & 4,4 & \\
\hline
\end{tabular}

Tabel 2. Keterpaparan Rokok di dalam Rumah Berdasarkan Status Perokok

\begin{tabular}{lcccc}
\hline \multicolumn{1}{c}{ Variabel } & $\begin{array}{c}\text { Perokok Aktif } \\
(\mathbf{\%})(\mathbf{n = 2 . 8 5 5})\end{array}$ & $\begin{array}{c}\text { Mantan Perokok } \\
(\mathbf{\%})(\mathbf{n = 5 5 5})\end{array}$ & $\begin{array}{c}\text { Tidak Pernah Merokok } \\
\mathbf{( \% )}(\mathbf{n = 4 . 8 9 5})\end{array}$ & $\begin{array}{c}\text { Total \% } \\
(\mathbf{n = 8 . 3 0 5})\end{array}$ \\
\hline Kebijakan Merokok dalam Rumah & & & & \\
Diizinkan & 53,4 & 41,3 & 43,6 & 46,9 \\
Tidak diizinkan, dengan pengecualian & 11,9 & 24,3 & 17,1 & 15,8 \\
Tidak pernah diizinkan & 4,2 & 13,4 & 10,7 & 8,6 \\
Tidak ada peraturan & 29,8 & 20,5 & 27,6 & 27,9 \\
Tidak tahu & 0,7 & 0,5 & 0,9 & 0,8 \\
Durasi merokok dalam rumah & & & & \\
Setiap hari & 78,8 & 36,1 & 55,0 & 62,5 \\
Setiap minggu & 11,2 & 19,9 & 14,7 & 13,7 \\
Setiap bulan & 4,2 & 15,7 & 10,5 & 8,5 \\
Kurang dari setiap bulan & 3,7 & 18,8 & 12,3 & 9,5 \\
Tidak pernah ada & 1,4 & 8,3 & 5,8 & 4,4 \\
Tidak tahu/menolak & 0,8 & 1,2 & 1,7 & 1,3 \\
\hline
\end{tabular}

responden tentang kebijakan kantor tentang merokok di ruang tertutup. Secara umum kantor yang mengizinkan merokok dalam ruang kerja tertutup sebesar $38.4 \%$, yang tidak mengizinkan sebesar $41.8 \%$, dan yang tidak ada kebijakan merokok dalam ruang tertutup sebesar $19.8 \%$.

Kondisi ini menjelaskan bahwa masih banyak kantor, baik kantor pemerintahan ataupun swasta yang kesadaran tentang bahaya merokok khususnya di ruang tertutup sangat kurang. Ada juga kantor yang tidak punya kebijakan tentang merokok dalam ruang tertutup. Kondisi ini membuktikan bahwa sosialisasi tentang Kawasan Tanpa Rokok (KTR) belum berjalan dengan baik. Padahal kantor punya wewenang yang kuat untuk melarang merokok di dalam ruang tertutup. 
Tabel 3. Keterpaparan Rokok di Tempat Kerja Berdasarkan Status Perokok

\begin{tabular}{lcccc}
\hline \multicolumn{1}{c}{ Variabel } & $\begin{array}{c}\text { Perokok } \\
\text { Aktif }(\%) \\
(\mathbf{n = 2 . 8 5 5 )}\end{array}$ & $\begin{array}{c}\text { Mantan } \\
\text { Perokok (\%) } \\
(\mathbf{n = 5 5 5 )}\end{array}$ & $\begin{array}{c}\text { Tidak Pernah } \\
\text { Merokok }(\mathbf{\%}) \\
(\mathbf{n}=\mathbf{4 . 8 9 5})\end{array}$ & $\begin{array}{c}\text { Total } \\
\mathbf{\%} \\
(\mathbf{n}=\mathbf{8 . 3 0 5})\end{array}$ \\
\hline $\begin{array}{l}\text { Kebijakan merokok di ruang tertutup di tempat } \\
\text { kerja }\end{array}$ & & & & \\
Di izinkan & 42.6 & 43.7 & 33.9 & 38.4 \\
Tidak di izinkan & 33.6 & 38.2 & 49.4 & 41.8 \\
Tidak ada kebijakan & 23.8 & 18.1 & 16.7 & 19.8 \\
Tidak tahu/menolak & 0.0 & 0.0 & 0.0 & 0.0 \\
Merokok di ruang tertutup di tempat kerja & & & & \\
Ya & 61.2 & 48.5 & 43.9 & 51.4 \\
Tidak & 35.6 & 48.5 & 53.3 & 45.6 \\
Tidak tahu/menolak & 3.2 & 3.0 & 2.8 & 3.0 \\
\hline
\end{tabular}

Jika dilihat dari pernyataan responden yang menyatakan bahwa ada yang merokok di ruang tertutup, secara umum ada $51.4 \%$ yang merokok di dalam ruang tertutup kantor. Persentase ini menjelaskan bahwa masih banyak orang yang merokok dalam ruang tertutup, walaupun kantor tersebut melarang merokok di dalam ruang tertutup.

Tabel 4 menjelaskan tentang merokok di fasilitas umum. Responden yang ditanyakan tentang kunjungan ke fasilitas umum dalam 30 hari terakhir dan ditanyakan apakah melihat ada orang yang merokok, secara keseluruhan $66.4 \%$ menyatakan ada yang merokok di kantor pemerintahan. Kelompok perokok aktif menyatakan ada yang merokok di kantor pemerintah sebesar $75.6 \%$, pada mantan perokok $70.9 \%$, dan terendah pada kelompok tidak pernah merokok sebesar $59.1 \%$.

Responden yang melakukan kunjungan ke universitas, $55.3 \%$ menyatakan ada yang merokok di universitas. Pada kelompok perokok aktif yang melihat ada yang merokok di universitas sebesar $52.7 \%$, pada kelompok tidak pernah merokok $59.7 \%$, dan kelompok mantan perokok sebesar 32.5\%.

Responden yang melakukan kunjungan ke sekolah atau fasilitas pendidikan lainnya, 40.3\% menyatakan ada yang merokok di sekolah atau fasilitas pendidikan lainnya. Pada kelompok perokok aktif menyatakan bahwa $46.6 \%$ melihat orang merokok di sekolah atau fasilitas pendidikannya, pada kelompok mantan perokok $43.8 \%$, dan pada kelompok tidak pernah merokok sebesar 37.6\%.

Responden yang melakukan kunjungan ke fasilitas kesehatan, 18.4\% menyatakan ada yang merokok di fasilitas kesehatan. Pada kelompok perokok aktif menyatakan bahwa $92.8 \%$ melihat orang merokok di rumah makan, pada kelompok mantan perokok $87.8 \%$, dan pada kelompok tidak pernah merokok sebesar $80.8 \%$.

Responden yang melakukan kunjungan ke bar atau club malam, $91.8 \%$ menyatakan ada yang

Tabel 4. Keterpaparan Rokok di Fasilitas Umum Berdasarkan Status Perokok

\begin{tabular}{lcccc}
\hline \multicolumn{1}{c}{ Variabel } & $\begin{array}{c}\text { Perokok } \\
\text { Aktif (\%) }\end{array}$ & $\begin{array}{c}\text { Mantan } \\
\text { Perokok (\%) }\end{array}$ & $\begin{array}{c}\text { Tidak Pernah } \\
\text { Merokok (\%) }\end{array}$ & $\begin{array}{c}\text { Total (\%) } \\
\text { Merokok di kantor pemerintahan }\end{array}$ \\
Merokok di universitas & 75.6 & 70.9 & 59.1 & 66.4 \\
Merokok di sekolah atau fasilitas pendidikan lainnya & 42.7 & 32.5 & 59.7 & 55.3 \\
Merokok di fasilitas keagamaan & 23.7 & 43.8 & 37.6 & 40.3 \\
Merokok di fasilitas layanan kesehatan & 22.1 & 17.1 & 13.7 & 17.9 \\
Merokok di rumah makan & 92.8 & 87.8 & 16.6 & 18.4 \\
Merokok di bar atau club malam & 92.1 & 44.0 & 80.8 & 86.4 \\
Merokok di transportasi umum & 79.9 & 71.0 & 100.0 & 91.8 \\
\hline
\end{tabular}


merokok di bar atau club malam. Pada kelompok perokok aktif menyatakan bahwa 92.1\% melihat orang merokok di bar atau club malam, pada kelompok tidak pernah merokok $100 \%$, dan pada kelompok mantan perokok sebesar $44.0 \%$.

Responden yang naik transportasi umum, $70.8 \%$ menyatakan ada yang merokok di dalam transportasi umum. Pada kelompok perokok aktif, yang melihat orang merokok dalam transportasi umum sebesar $79.9 \%$, kelompok mantan perokok $71.0 \%$, dan pada kelompok tidak pernah merokok sebesar $66.2 \%$.

Berdasarkan hasil di atas, terbukti bahwa perokok pasif masih belum terlindungi dari perokok aktif. Pengendalian masalah rokok belum ditata dengan baik, dan peraturan kawasan tanpa rokok belum berlaku di seluruh wilayah Indonesia.

\section{Pembahasan}

Kawasan Tanpa Rokok (KTR) sudah ditetapkan, namun sampai saat ini aplikasi pelaksanaan kebijakan tersebut belum berjalan dengan baik. Kebijakan KTR belum berjalan sesuai dengan yang diharapkan. Jika kita pergi ke tempattempat umum yang termasuk dalam Kawasan Tanpa Rokok (KTR), ternyata para perokok aktif masih terus melakukan pelanggaran, dan tidak perduli dampak yang ditimbulkan terhadap orang lain. Perokok pasif dapat terpapar rokok di dalam ruangan kerja, rumah, dan tempat-tempat umum seperti gedung pemerintahan, fasilitas pelayanan kesehatan, restoran dan transportasi umum. Hasil analisis menjelaskan bahwa kesadaran masyarakat tentang bahaya merokok di tempat-tempat umum masih sangat rendah. Masyarakat yang berada di tempat-tempat umum nyaris tak terlindungi. Masyarakat yang bukan perokok juga terkena dampaknya, mereka tidak punya hak untuk bebas dari asap rokok dan bebas menghirup udara segar. Tingginya paparan rokok pada fasilitas pendidikan dan kesehatan menunjukkan lemahnya penegakan aturan KTR. Penelitian di Sumatera Barat juga menunjukkan bahwa kebijakan KTR pada tiga kota cenderung tidak efektif karena belum ada sangsi yang tegas dari pemerintah. ${ }^{7}$ Penelitian lain juga menjelaskan implementasi di sekolah tidak efektif karena kurangnya komitmen dan sangsi yang tegas. ${ }^{8}$ Asap rokok orang lain (AROL) sangat berbahaya bagi bukan perokok atau perokok pasif karena merupakan campuran antara asap dan partikel. Data WHO 2009, menunjukkan bahwa korban kematian akibat AROL terutama pada kelompok rentan, anak-anak sebesar $31 \%$ dan perempuan sebesar 64\%. Data Riskesdas 2010, menunjukkan bahwa 92 juta warga Indonesia terpapar asap rokok orang lain (AROL), 43 juta diantaranya merupakan anak-anak, termasuk 11,4 juta anak usia 0-4 tahun. ${ }^{4}$ Asap rokok di dalam rumah akan berdampak terhadap anggota keluarga khususnya anak balita. ${ }^{9}$ Peningkatan jumlah perokok baik aktif maupun pasif, akan berdampak pada besarnya beban biaya penyakit akibat rokok yang sebenarnya merupakan perilaku yang dapat dicegah. Lebih lanjut beban waktu produktif yang hilang dan kondisi disabilitas karena kondisi sakit (penyakit akibat merokok) menjadi beban ekonomi akibat rokok. ${ }^{10}$

Paparan asap rokok sangat tinggi di tempattempat umum, namun durasi paparan lebih banyak di rumah atau di tempat kerja. Kebijakan yang tepat untuk mengurangi paparan asap rokok di rumah atau kantor sangat diperlukan. Selain larangan merokok, bisa juga diberikan rewards kepada kantor yang benar-benar menerapkan Kawasan Tanpa Rokok. Penerapan KTR sebagai bentuk perlindungan bagi para perokok pasif, edukasi tentang bahaya perokok, perlu juga diketahui determinan yang terkait dengan keterpaparan perokok pasif di lingkungan perokok aktif seperti tentang kebijakan merokok di lingkungan rumah tempat tinggal, serta paparan perokok aktif di lingkungan rumah, tempat kerja dan fasilitas umum lainnya. Sejak ditetapkan PP No 109 Tahun 2012, beberapa pemerintah daerah sudah mengadopsi PP tersebut ke berbagai aturan daerah baik pada level provinsi maupun kabupaten/kota.

Perilaku merokok di sembarangan tempat masih merupakan budaya yang sulit untuk diubah dan cenderung tidak peduli terhadap dampak yang ditimbulkan pada lingkungannya. Peraturan kawasan tanpa rokok yang sudah berlaku juga belum berjalan dengan baik. Selanjutnya pemerintah dan para pemerhati kesehatan perlu mengupayakan penegakan aturan KTR dengan pemberian sanksi yang tegas bagi para pelanggar aturan KTR. Untuk melindungi masyarakat dari paparan asap rokok, khususnya kepada perokok pasif, pemerintah harus meningkatkan koordinasi lintas sektor, sehingga 
institusi yang terlibat dapat mengambil peran untuk penanggulangan dampak bahaya merokok terhadap masyarakat khususnya kelompok bukan perokok. Institusi yang terlibat antara lain Kementerian Kesehatan, Kementerian Pendidikan, Kementerian Perhubungan, Kementerian Agama, PEMDA, dan institusi lainnya.

Selain program pengendalian tembakau melalui penegakan aturan KTR, pemerintah juga perlu menyediakan layanan berhenti merokok.

Layanan berhenti merokok ini dapat diakses masyarakat Indonesia melalui berbagai fasilitas kesehatan yang tersedia baik di fasilitas layanan kesehatan primer seperti puskesmas, klinik dan praktek mandiri, maupun di fasilitas kesehatan rujukan di rumah sakit. Selain di fasilitas kesehatan, sejak tahun 2016 kementerian kesehatan membuka layanan konseling melalui telepon bebas pulsa atau yang dikenal dengan 'Quit Line'. Konsultasi meliputi screening awal, pengumpulan informasi demografi dan riwayat merokok penelpon.

Konseling mendalam untuk beberapa penelepon dengan cara memberikan informasi praktis cara berhenti merokok, keterampilan membangun kepercayaan diri dan peningkatan motivasi, serta dukungan sosial. Kemampuan konseling petugas kesehatan, peningkatan metode terapi berhenti merokok dan media promosi kesehatan juga merupakan hal yang perlu ditingkatkan fasilitas serta kompetensi petugasnya.

Pada umumnya perokok pasif adalah perempuan dan anak-anak, sehingga perlu diupayakan peningkatan pengetahuan dan kesadaran masyarakat melalui edukasi interaktif tentang bahaya perokok pasif dan upaya-upaya komunikasi efektif membangun kesadaran untuk melarang merokok di area publik, terutama di dalam rumah atau ruang tertutup lainya, fasilitas pendidikan, fasilitas kesehatan, perkantoran dan transportasi umum. ${ }^{11}$ Kebijakan untuk mengurangi paparan asap rokok di semua lokasi baik indoor maupun outdoor dapat membantu mencegah kematian dini dan mengurangi kematian, dan mengurangi beban ekonomi karena rokok. ${ }^{12}$ Akses terhadap layananlayanan tersebut harus menjadi perhatian bersama antara masyarakat dan pemerintah. Implementasi penegakan KTR, perluasan akses layanan berhenti merokok serta promosi dan edukasi masyarakat baik perokok pasif maupun perokok aktif akan lebih efektif jika dijalankan secara simultan. Koordinasi lintas sektor di pusat dan daerah dibutuhkan agar program dan kebijakan pengendalian tembakau dapat berjalan efektif sehingga pada akhirnya dapat menekan peningkatan jumlah perokok di Indonesia.

\section{Kesimpulan}

Kesadaran perokok aktif terhadap bahaya yang ditimbulkan terhadap lingkungan sekitar masih sangat rendah. Hal ini terbukti dari masih tingginya keterpaparan perokok pasif akibat asap rokok, baik pada lingkungan sekitar (rumah dan kantor) dan juga pada tempat-tempat umum, seperti sekolah atau fasilitas pendidikan lainnya, tempat ibadah, tempat bermain, tempat kerja, angkutan umum, dan tempat umum lainnya. Implementasi KTR belum berjalan efektif, kesadaran masyarakat untuk tidak merokok di tempat-tempat umum dan juga di rumah masih sangat rendah. Dukungan pemerintah terhadap peringatan bahaya merokok di tempattempat umum belum maksimal. Hal ini terlihat dari masih banyaknya fasilitas umum yang mengizinkan atau tidak membuat peraturan yang jelas dan tegas tentang larangan merokok di tempat-tempat umum.

\section{Saran}

Meningkatkan sosialisasi dan edukasi tentang bahaya merokok di tempat-tempat umum dan dampaknya terhadap masyarakat yang bukan perokok oleh institusi yang terkait. Membuat peraturan yang jelas dan tegas tentang pelarangan merokok di tempat-tempat umum, dan memberikan sangsi yang tegas terhadap orang-orang yang melanggar peraturan tersebut. Menyediakan layanan berhenti merokok dengan memperluas dan menjamin akses masyarakat terhadap layanan tersebut. Koordinasi lintas sektor pemerintah pusat dan daerah untuk penegakan aturan pengendalian tembakau.

\section{Daftar Rujukan}

1. Peraturan Pemerintah Republik Indonesia Nomor 109 Tahun 2012 Tentang Pengamanan Bahan yang Mengandung Zat Aditif Berupa Produk Tembakau bagi Kesehatan.

2. TCSC - IAKMI. FAKTA TEMBAKAU dan permasalahannya di Indonesia [Internet]. 2014. 189 p. Available from: http://www.tcsc- 
indonesia.org/wp-content/uploads/2016/06/ Buku-Fakta-Tembakau-2014__Web-Version. pdf

3. Badan Penelitian dan Pengembangan Kesehatan. Laporan Nasional Riskesdas 2007 [National Report on Basic Health Research 2007]. Kemenkes RI. 2008;1-384.

4. Kementerian Kesehatan RI. Riset Kesehatan Dasar (RISKESDAS 2010). Lap Nas 2010. 2010;78.

5. World Health Organization RO for S-EA. Global adult tobacco survey: Indonesia report 2011 [Internet]. New Delhi PP - New Delhi: WHO Regional Office for South-East Asia; 2012. Available from: https://apps.who.int/iris/ handle/10665/205137

6. Byron MJ, Suhadi DR, Hepp LM, Avila-Tang E, Yang J, Asiani G, et al. Secondhand tobacco smoke in public venues in three Indonesian cities. Med J Indones [Internet]. 2013 Dec 13;22(4 SE-Community Research). Available from: https://mji.ui.ac.id/journal/index.php/mji/ article/view/606

7. Azkha N. Studi Efektivitas Penerapan Kebijakan Perda Kota Tentang Kawasan Tanpa Rokok
(Ktr) Dalam Upaya Menurunkan Perokok Aktif Di Sumatera Barat Tahun 2013. Kebijak Kesehat Indones. 2013;02(04):171-9.

8. Marchel YA. Implementasi Kawasan Tanpa Rokok Sebagai Pencegahan Merokok Pada Remaja Awal. J PROMKES. 2019;7(2):144.

9. Sihombing M, Notohartojo IT. Faktor yang Berhubungan dengan Kejadian ISPA pada Balita di Indonesia (Analisis Data Riskesdas 2013). J Ekol Kesehat. 2015;14(4):284-95.

10. Permitasari NPAL, Satibi S, Kristina SA. National burden of cancers attributable to secondhand smoking in Indonesia. Asian Pacific J Cancer Prev. 2018;19(7):1951-5.

11. Öberg M, Jaakkola MS, Woodward A, Peruga A, Prüss-Ustün A. Worldwide burden of disease from exposure to second-hand smoke: A retrospective analysis of data from 192 countries. Lancet. 2011;377(9760):139-46.

12. Chen J, Wang MP, Wang X, Viswanath K, Lam TH, Chan SS. Secondhand smoke exposure (SHS) and health-related quality of life (HRQoL) in Chinese never smokers in Hong Kong. BMJ Open. 2015;5(9):16-8. 